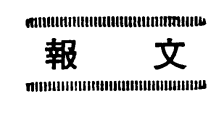

\title{
淡水中の鉄鋼構造物の防食塗装*
}

\author{
後藤田正夫** 佐 藤 靖** 関口吉 造**
}

\section{Coatings for Underwater Steel Structures in Fresh Water Exposures}

\author{
Masao Gotôda, Yasushi Satô and Kichizô Sekiguchi
}

Anticorrosive coating of steel structures has been undertaken since long, but reports on tests performed in fresh water are relatively few.

The authors have carried out long term immersion test, extending over three and half years on test steel pannels coated with over 30 kinds of commercial paints, for the purpose of selecting suitable anticorrosive paints to be used for the gate of hydroelectric station of J. N. R., at Sinano river.

The results indicated that vinyl resin paint, Cummaron resin paint, and coal tar enamel gives the good performance. Phenol resin paint was found irregular in quality according to make, and requires caution in its selection. Zinc rich paint did not perform well under the present tests.

\section{1. 序論}

鉄鋼構造物の防食塗装は古くから行なわれ，かつその 重要性からも着実な進歩を見せている。しかし戸外また は海水中に比して淡水用に関する研究報告は比較的少な W1)。

そこでわれわれは国鉄給電管理事務所の依頼により信 濃川上流の干手および小千谷両水力発電所の水路構造物 特に制水門屝および圧力ずい道を対象として防食塗装の 総合的試験研究を行なった。

従来よりこのような水中構造物の塗装には各種の塗料 が使用されているが，それぞれの防食原理, 組成, 塗装 法を異にし，それぞれ特長を有しているのであるが， これらの総合的な比較は従来あまり行なわれていなか った。そこで各種塗料塗装試験片を同時に水中浸漬試 験を行ない, 各々の利害得失の検討を行なうこととし た。

Hess $^{2)}$ は制水門屝の防食塗装の 実際試験 においてサ ン.ドブラスト後燐酸またはウォッシュプライマー処理し 塗装することによりこのような処理を伴なわぬものに比 して $2 \sim 5$ 年寿命を延長せしめ得られるし，またホット スプレー塗装が有望であることをも述べている22。

しかし,このような構造物は多く山間僻地にあって最 良の塗装法が採用できない場合が多い。この場合も，サ ンドブラストおよびスプレー塗装は経済的に採用し得 ず，亜鉛メッキ等も既存施設を対象とする以上調査の対 象からはぶくこととした。

* 昭和 33 年 6 月 第 5 回腐食防食討論会（札幌）にて一部講演

** 鉄道技術研究所 (東京都北多摩郡国分寺町)
なお,これら塗料の現地浸漬試験結果の早期予測を行 なう目的で, 岡本·諸住の塭水中のインピーダンスの周波 数特性測定3)を水道水中にて行ない,これより得た $\tan \delta$ 值と実際とを比較し，本法の検討をも行なった。

ところで, 本試験の対象としたものは市販塗料であ る。従って本試験により不良な結果を得たものでもその 組成を変えることにより性能がかなり変更し得る可能性 があるものもあり得る。たとえば Pschorrir) はエポキシ 樹脂塗料の耐水, 耐薬品性が硬化戍の種類に左右される ことを述べており, 塗料の見かけの品質によりこの試験 結果のみからその種の塗料全体の性能を速断することは 危険な場合があり得ることを付言しておきたい。

\section{2. 試験片の作成法}

供試塗料は 33 種あって, そのうち 10 種はこの試験の ためとくに作製したものであり，他は市販品である。主 としてビヒクルによって分類すれば, 油性系 4, 石炭酸 樹脂系 7 , クマロン樹脂系 6 , 掹化ビニル樹脂系 7 , 瀝 青系 4 , 加熱型コールタールエナメル 3 , ジンクリッチ ペイント 3 となる。

インピーダンス測定用試験片は $50 \times 100 \times 1 \mathrm{~mm}$ の高 級仕上鋼板を研摩布 \#180でよく磨き, トリクレンおよ びアセトンで脱脂して塗装した。浸漬試験用試験片は $300 \times 300 \times 1.6 \mathrm{~mm}$ または $300 \times 150 \times 1.6 \mathrm{~mm}$ の普通 軟鋼板を酸洗, ワイヤブラシ磨き, アルカリ浸漬後研摩 布\#100でよく磨き，アセトンで脱脂後塗装した。なお 塗装はコールタールェナメル以外は刷毛塗りによった。

供試塗料の概要, 塗回数, 平均膜厚, 作業性の難易を まとめて表 1 に示した。 
表 1 供試鋈料の概要

\begin{tabular}{|c|c|c|c|c|c|c|}
\hline \multirow{2}{*}{$\begin{array}{l}\text { 試 } \\
\text { 皤 } \\
\text { 竟 }\end{array}$} & \multirow[b]{2}{*}{ ビヒクルの系統 } & \multirow{2}{*}{ 主要顔 料 } & \multirow{2}{*}{$\begin{array}{l}\text { 谽 } \\
\text { 回 } \\
\text { 数 }\end{array}$} & \multicolumn{2}{|c|}{ 平均膜厚 $(\mu)$} & \multirow{2}{*}{$\begin{array}{l}\text { 作 } \\
\text { 業 } \\
\text { 性 }\end{array}$} \\
\hline & & & & 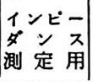 & $\mid \begin{array}{ll}\text { 浸 } & \text { 滇 } \\
\text { 試験用 }\end{array}$ & \\
\hline $\begin{array}{l}23 \\
24 \\
25 \\
13\end{array}$ & 油性 系 & 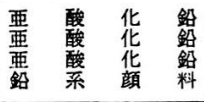 & $\left|\begin{array}{c}3 \\
3 \\
w 3 \\
4\end{array}\right|$ & $\begin{array}{r}110 \\
89 \\
93\end{array}$ & $\begin{array}{l}108 \\
101 \\
160 \\
102\end{array}$ & $\begin{array}{l}0 \\
8 \\
0\end{array}$ \\
\hline 1 & & 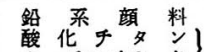 & 2 & - & 77 & $\Delta$ \\
\hline $\begin{array}{l}12 \\
28 \\
29 \\
30 \\
31\end{array}$ & 石炭酸烓脂系 & 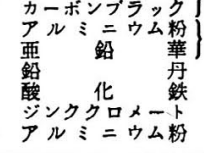 & $\begin{array}{l} \\
4 \\
2 \\
2 \\
2 \\
2\end{array}$ & $\begin{array}{r}150 \\
53 \\
140 \\
54 \\
30\end{array}$ & $\begin{array}{l}6 \\
99 \\
65 \\
69 \\
71 \\
52\end{array}$ & $\begin{array}{l}\triangle \\
0 \\
0 \\
0 \\
0\end{array}$ \\
\hline $\begin{array}{r}7 \\
8 \\
32 \\
33 \\
34 \\
35\end{array}$ & クマロン樹脂系 & 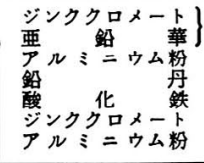 & $\begin{array}{l}4 \\
4 \\
2 \\
2 \\
2 \\
2\end{array}$ & $\begin{array}{r}180 \\
120 \\
115 \\
205 \\
88 \\
115\end{array}$ & $\begin{array}{r}129 \\
101 \\
82 \\
65 \\
81 \\
46\end{array}$ & $\begin{array}{l}\Delta \\
\Delta \\
\Delta \\
\Delta \\
\Delta\end{array}$ \\
\hline $\begin{array}{l}22 \\
36 \\
37\end{array}$ & 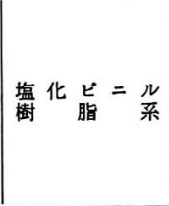 & 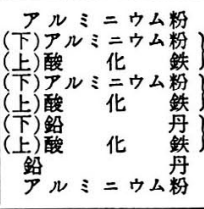 & $\begin{array}{l}\text { W6 } \\
\text { W5 } \\
\text { W4 } \\
\text { W4 }\end{array}$ & $\begin{array}{l}- \\
- \\
- \\
- \\
98 \\
72\end{array}$ & $\begin{array}{r}35 \\
46 \\
51 \\
146 \\
74 \\
70\end{array}$ & $\begin{array}{l}\Delta \\
\Delta \\
\Delta\end{array}$ \\
\hline $\begin{array}{l}2 \\
3 \\
4 \\
5\end{array}$ & 㱘 青 系 & & $\begin{array}{l}3 \\
3 \\
3 \\
3\end{array}$ & $\begin{array}{r}115 \\
140 \\
=\end{array}$ & $\begin{array}{l}42 \\
56 \\
19 \\
54\end{array}$ & $\begin{array}{l}0 \\
\times \\
0 \\
0\end{array}$ \\
\hline $\begin{array}{l}17 \\
18 \\
21\end{array}$ & 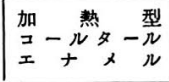 & & $\begin{array}{l}2 \\
2 \\
2\end{array}$ & $\bar{z}$ & 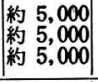 & $\begin{array}{l}x \\
x \\
x\end{array}$ \\
\hline $\begin{array}{l}10 \\
15 \\
16\end{array}$ & 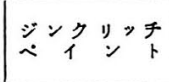 & $\begin{array}{ll}\text { 亜 鉛 } \\
\text { 鉛 } \\
\text { 重 }\end{array}$ & $\begin{array}{l}3 \\
2 \\
1\end{array}$ & $\bar{z}$ & $\begin{array}{r}81 \\
115 \\
25\end{array}$ & $\begin{array}{l}\vec{x} \\
\Delta\end{array}$ \\
\hline
\end{tabular}

(注)(1) $O$ : 良好, $\triangle$ : 普通, $x$ : 不良

(2) 㳂回数の項でだとえばW3はウォッシニブライマー1回㳂りの 後供試叙料を 3 回塗りしたことを示す。

3. インピーダンスの測定

前記の試片を $200 \mathrm{cc}$ のビーカー内で水道水に浸漬し， ブリキ製の電極を対極として，試片のインピーダンスの 周波数特性を測定した。溶液抵抗の影響を小さくするた めに対極は箱型に作り，この中の一定位置に試験片を挿

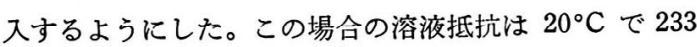
$\Omega$ であった。インピータ゚ンスの測定值に次式引)を用いて 溶液抵抗の補正を行ない，試片のインピーダンスとし た。

$$
\begin{aligned}
& R=\left[\left(R^{\prime}-R_{S}\right)^{2}+\left(\omega C^{\prime} R^{\prime} R_{S}\right)^{2}\right] / \\
& {\left[\left(R^{\prime}-R_{S}^{\prime}\right)-\left(\omega C^{\prime} R^{\prime}\right)^{2} R_{S}\right]} \\
& C=C^{\prime} R^{\prime 2} /\left[\left(R^{\prime}-R_{S}\right)^{2}+\left(\omega C^{\prime} R^{\prime} R_{S}\right)^{2}\right]
\end{aligned}
$$

浸漬当初試片の抵抗は徐々に低下し, 容量は徐々に增 大するが，3 日後にはほぼ安定な值を示すようになっ た。この期間においては塗膜の劣化は認められず，また 抵抗および容量の周波数特性の状況よりみて，浸漬 3 日
後のインピーダンスの值は被塗金属面のインピーダンス をふくまず全く塗膜の性質を表わしているものと見て差 支えない。従ってこの值より塗膜の $\tan \delta$ を求め防食性 の早期予測を行なった。

Brasher ら ${ }^{6)}$ によれば，塗膜内に吸収された水分が， 任意に均一に分散している場合には電父容量の測定值よ り吸水量を算出し得る。

すなわち

$$
\begin{gathered}
X_{V}=100 \times \log \left(C_{m} / C_{m o}\right) / \log 80 \\
X_{V}: \text { 塗膜の吸水量 }(\mathrm{vol} \%) \\
C_{m}: \text { 塗装試片の電気容量 }
\end{gathered}
$$

\begin{tabular}{|c|c|c|c|c|}
\hline & \multirow{2}{*}{ 試片番号 } & \multicolumn{2}{|c|}{$\tan \delta$} & \multirow{2}{*}{$\begin{array}{c}\text { 吸水 } \\
(\text { vol } \%)\end{array}$} \\
\hline & & $10 \mathrm{kc}$ & $0.12 \mathrm{kc}$ & \\
\hline $\begin{array}{l}\text { 油 } \\
\text { 笔 }\end{array}$ & $\begin{array}{l}23 \\
24 \\
25\end{array}$ & $\begin{array}{l}0.093 \\
0.12 \\
0.10\end{array}$ & $\begin{array}{l}0.16 \\
0.20 \\
0.20\end{array}$ & $\begin{array}{l}13.7 \\
12.6 \\
13.3\end{array}$ \\
\hline 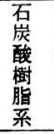 & $\begin{array}{l}12 \\
28 \\
29 \\
30 \\
31\end{array}$ & $\begin{array}{l}0.068 \\
0.11 \\
0.11 \\
0.13 \\
0.029\end{array}$ & $\begin{array}{l}0.078 \\
0.15 \\
0.075 \\
0.21 \\
0.049\end{array}$ & $\begin{array}{r}4.2 \\
8.2 \\
10.5 \\
12.4 \\
2.6\end{array}$ \\
\hline 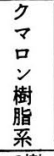 & $\begin{array}{r}7 \\
8 \\
32 \\
33 \\
34 \\
35\end{array}$ & $\begin{array}{l}0.085 \\
0.059 \\
0.058 \\
0.067 \\
0.070 \\
0.058\end{array}$ & $\begin{array}{l}0.093 \\
0.052 \\
0.064 \\
0.087 \\
0.16 \\
0.12\end{array}$ & $\begin{array}{l}1.2 \\
2.0 \\
2.5 \\
1.3 \\
2.8 \\
3.0\end{array}$ \\
\hline $\begin{array}{l}\text { ビ樹 } \\
\text { 二脂 } \\
\text { 几系 }\end{array}$ & $\begin{array}{l}36 \\
37\end{array}$ & $\begin{array}{l}0.070 \\
0.078\end{array}$ & $\begin{array}{l}0.12 \\
0.10\end{array}$ & $\begin{array}{l}0.92 \\
0.78\end{array}$ \\
\hline $\begin{array}{l}\text { 涯 } \\
\text { 青 } \\
\text { 系 }\end{array}$ & $\begin{array}{l}2 \\
3\end{array}$ & $\begin{array}{l}0.087 \\
0.053\end{array}$ & $\begin{array}{l}0.19 \\
0.26\end{array}$ & $\begin{array}{l}1.3 \\
2.3\end{array}$ \\
\hline
\end{tabular}$$
C_{m o} \text { : 浸漬直後の塗装試片の電気容量 }
$$

浸漬開始より 3 日後における各染装試片の $\tan \delta$ の值 と (2) 式によって算出した吸水量の值は表 2 のごとくで

表 2 塗装試片の $\tan \delta$ と吸水量

ある。この数值の中で試料 No. 31 の吸水量が同種ビヒ クルの他の試料より著しく小さくなっているのは, 顔料 のアルミニウム粉が塗面に平行に並ぶ性質を有するため

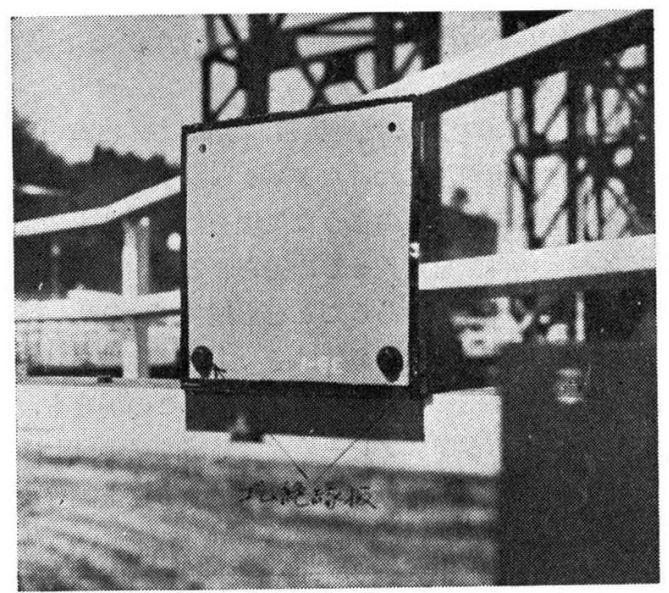

図 1 塗装試験片 
Vol. 11, No. 9

淡水中の鉄鋼構造物の防食塗装

表 3 浸漬試験片の調査結果

\begin{tabular}{|c|c|c|c|c|c|c|c|c|c|c|}
\hline \multirow{2}{*}{$\begin{array}{l}\text { 試片 } \\
\text { 番号 }\end{array}$} & \multicolumn{5}{|c|}{ 第 1 回調 查 $(31-8-10)$} & \multicolumn{5}{|c|}{ 第 2 回調 查 $(31-12-4)$} \\
\hline & $s<れ$ & はがれ & 錆 & その他 & 殓断值 & $s<れ$ & はがれ & 錆 & その他 & 診断 值 \\
\hline $\begin{array}{l}23 \\
24 \\
25 \\
13\end{array}$ & $\begin{array}{l}x \times \\
x \\
x \times \\
x \times\end{array}$ & $\begin{array}{l}0 \\
0 \\
0 \\
0\end{array}$ & $\begin{array}{l}8 \\
8 \\
0\end{array}$ & 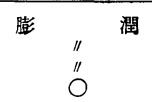 & $\begin{array}{r}140 \\
100 \\
10 \\
2\end{array}$ & $\begin{array}{l}x \times \\
\times x \\
x \times \\
x \times\end{array}$ & $\begin{array}{c}x \times \\
x \\
0 \\
0\end{array}$ & $\begin{array}{l}x \times \\
x \times \\
x \times x \\
x\end{array}$ & $\begin{array}{l}\text { 部溶失 } \\
\text { 数化, 粉 化 }\end{array}$ & $\begin{array}{l}66 \sim 83 \\
76 \sim 78 \\
17 \sim 18 \\
3 \sim 9\end{array}$ \\
\hline $\begin{array}{r}1 \\
6 \\
12 \\
28 \\
29 \\
30 \\
31\end{array}$ & $\begin{array}{c}x \times \\
x \\
x \\
x \\
x \\
0 \\
0 \\
0\end{array}$ & $\begin{array}{l}8 \\
8 \\
8 \\
8 \\
8 \\
0\end{array}$ & $\begin{array}{l}0 \\
x \\
0 \\
0 \\
0 \\
0 \\
0 \\
0\end{array}$ & $\begin{array}{l}8 \\
8 \\
8 \\
8 \\
8 \\
0\end{array}$ & $\begin{array}{r}0 \\
110 \\
1 \\
6 \\
6 \\
0 \\
0\end{array}$ & $\begin{array}{l}x \times \\
x \times \\
\times x \\
x \\
x \\
x \\
0 \\
x\end{array}$ & $\begin{array}{l}8 \\
8 \\
8 \\
8 \\
8 \\
0\end{array}$ & $\begin{array}{c}x \\
x \times \\
x \\
0 \\
0 \\
8 \\
0\end{array}$ & $\begin{array}{l}8 \\
8 \\
8 \\
8 \\
8 \\
0\end{array}$ & $\begin{array}{c}0 \sim 1 \\
130 \sim 150 \\
3 \sim 4 \\
3 \sim 6 \\
3 \sim 13 \\
12 \sim 13 \\
1 \sim 2 \\
+\end{array}$ \\
\hline $\begin{array}{r}7 \\
8 \\
32 \\
33 \\
34 \\
35\end{array}$ & $\begin{array}{l}8 \\
8 \\
8 \\
0 \\
\times \\
0\end{array}$ & $\begin{array}{l}8 \\
8 \\
8 \\
8 \\
0\end{array}$ & $\begin{array}{l}8 \\
8 \\
8 \\
8 \\
0\end{array}$ & $\begin{array}{l}8 \\
8 \\
8 \\
8 \\
0\end{array}$ & $\begin{array}{l}0 \\
0 \\
0 \\
0 \\
0 \\
0\end{array}$ & $\begin{array}{l}0 \\
\stackrel{2}{0} \\
0 \\
\times \\
0\end{array}$ & $\begin{array}{l}8 \\
8 \\
8 \\
8 \\
0\end{array}$ & $\begin{array}{l}8 \\
8 \\
8 \\
8 \\
8 \\
0\end{array}$ & $\begin{array}{l}8 \\
0 \\
0 \\
8 \\
0\end{array}$ & $\begin{array}{l}0 \\
0 \\
+ \\
+ \\
0 \\
0\end{array}$ \\
\hline $\begin{array}{l}99 \\
11 \\
14 \\
22 \\
36 \\
37\end{array}$ & $\begin{array}{c}x \\
0 \\
0 \\
0 \\
x \times \\
x\end{array}$ & $\begin{array}{l}8 \\
8 \\
8 \\
8 \\
8 \\
\end{array}$ & $\begin{array}{l}8 \\
8 \\
8 \\
8 \\
0\end{array}$ & $\begin{array}{l}8 \\
8 \\
8 \\
8 \\
0\end{array}$ & $\begin{array}{l}0 \\
0 \\
0 \\
0 \\
0 \\
0\end{array}$ & $\begin{array}{c}x \\
0 \\
0 \\
x \\
\times x \\
x \\
x\end{array}$ & $\begin{array}{l}8 \\
8 \\
8 \\
8 \\
0\end{array}$ & $\begin{array}{l}8 \\
8 \\
8 \\
8 \\
0\end{array}$ & $\begin{array}{l}0 \\
8 \\
8 \\
8 \\
8 \\
8\end{array}$ & $\begin{array}{c}0 \sim 0.5 \\
0 \\
0 \\
0.5 \sim 1 \\
0 \\
0\end{array}$ \\
\hline $\begin{array}{l}2 \\
3 \\
4 \\
5\end{array}$ & $\begin{array}{l}0 \\
\times \\
\times \\
0\end{array}$ & $\begin{array}{l}8 \\
0 \\
x \times \\
0\end{array}$ & $\begin{array}{l}0 \\
8 \\
0 \\
x\end{array}$ & $\begin{array}{l}8 \\
8 \\
8\end{array}$ & $\begin{array}{c}1 \\
0 \\
300 \\
1 \sim 200\end{array}$ & $\begin{array}{l}0 \\
x \\
x \\
x\end{array}$ & $\begin{array}{c}0 \\
x \times \\
0\end{array}$ & 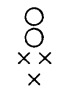 & $\begin{array}{l}\mathrm{O} \\
8 \\
8 \\
0\end{array}$ & $\begin{array}{c}1.5 \sim 10 \\
1 \sim 2 \\
58 \sim 160 \\
9 \sim 11\end{array}$ \\
\hline $\begin{array}{l}17 \\
18 \\
21\end{array}$ & $\begin{array}{l}\text { O } \\
8\end{array}$ & $\begin{array}{l}8 \\
8 \\
0\end{array}$ & 8 & $\begin{array}{l}8 \\
8 \\
0\end{array}$ & $\begin{array}{l}0 \\
0 \\
0\end{array}$ & 8 & $\begin{array}{l}8 \\
8\end{array}$ & $\begin{array}{l}8 \\
8 \\
8\end{array}$ & $\begin{array}{l}\text { O } \\
8 \\
0\end{array}$ & $\begin{array}{l}0 \\
0 \\
0\end{array}$ \\
\hline $\begin{array}{l}10 \\
15 \\
16\end{array}$ & $\begin{array}{l}x \times \\
x \times \\
0\end{array}$ & $\begin{array}{l}8 \\
8\end{array}$ & $\begin{array}{l}x \\
x \\
x\end{array}$ & $\begin{array}{l}8 \\
8\end{array}$ & $=$ & $\begin{array}{l}x \times \\
x \times \\
x \\
0\end{array}$ & $\begin{array}{l}0 \\
\text { x } \\
\text { Oे }\end{array}$ & $\begin{array}{l}x \times \\
x \times \\
x \times\end{array}$ & $\begin{array}{l}8 \\
8 \\
0\end{array}$ & $=$ \\
\hline
\end{tabular}

\begin{tabular}{|c|c|c|c|c|c|c|c|c|c|c|}
\hline \multirow{2}{*}{ 圾片 } & \multicolumn{5}{|c|}{ 第 3 回 調 査 $\quad(32-5-9)$} & \multicolumn{5}{|c|}{ 第 4 ～回 調 查 $(32-10-29)$} \\
\hline & $s<れ$ & はがれ & 錆 & その他 & 誜断 值 & s< $<れ$ & はがれ & 鏡 & その他 & 浐断值 \\
\hline $\begin{array}{l}23 \\
24 \\
25 \\
13\end{array}$ & $\begin{array}{l}\times x \\
\times x \\
0 \\
\times x\end{array}$ & $\begin{array}{l}x \times \\
x \\
x \times \\
x\end{array}$ & $\begin{array}{l}\times x \\
\times x \\
\times x \\
x\end{array}$ & $\begin{array}{l}\text { 一部溶 失 } \\
\text { 軟 }{ }^{\circ} \text {. 化 }\end{array}$ & $\begin{array}{l}45 \sim 150 \\
32 \sim 120 \\
5 \sim 30 \\
12 \sim 21\end{array}$ & $\begin{array}{c}x \times \\
x \times \\
0 \\
x \times x\end{array}$ & $\begin{array}{c}x \times \\
x \\
x \times \\
x \times x\end{array}$ & $\begin{array}{c}x \times x \\
x \times \\
x \times \\
x\end{array}$ & $\begin{array}{l}\text { 一部 溶 } \\
\text { 制 } \\
\text { 軟 } \\
0\end{array}$ & $\begin{array}{c}360 \sim 470 \\
60 \sim 160 \\
150 \sim 200 \\
5 \sim 6\end{array}$ \\
\hline $\begin{array}{r}1 \\
6 \\
12 \\
28 \\
29 \\
30 \\
31\end{array}$ & $\begin{array}{l}x \times \\
x \times \\
\times x \\
\times \\
x \\
x \\
0 \\
x\end{array}$ & $\begin{array}{l}0 \\
x \times \\
0 \\
8 \\
8 \\
0 \\
0\end{array}$ & $\begin{array}{l}x \\
\times x \\
\times x \\
\times \\
0 \\
x \\
0 \\
0\end{array}$ & 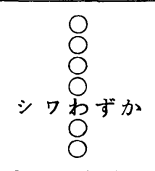 & $\begin{array}{c}1 \sim 1.5 \\
160 \sim 230 \\
10 \sim 28 \\
11 \sim 15 \\
7 \sim 8 \\
0 \sim 1 \\
0\end{array}$ & $\begin{array}{l}x \\
0 \\
\times x \\
\times x \\
x \times \\
\times x \\
x \\
x \\
x\end{array}$ & $\begin{array}{c}0 \\
x \times x \\
0 \\
0 \\
8 \\
0 \\
0\end{array}$ & $\begin{array}{c}x \\
x+x \\
x \times x \\
x \\
0 \\
x \\
0 \\
0\end{array}$ & $\begin{array}{l}\text { 局部 } \\
\text { O } \\
\text { シ } \\
\text { シ妿ずか } \\
\text { O }\end{array}$ & $\begin{array}{c}0 \\
300 \stackrel{370}{\sim} \\
10 \sim 26 \\
7 \\
3 \sim 5 \\
0 \sim 3 \\
0 \sim 0.5\end{array}$ \\
\hline $\begin{array}{r}7 \\
8 \\
32 \\
33 \\
34 \\
35\end{array}$ & $\begin{array}{l}0 \\
8 \\
8 \\
0 \\
\times \\
0\end{array}$ & $\begin{array}{l}8 \\
8 \\
8 \\
8 \\
0\end{array}$ & $\begin{array}{l}8 \\
8 \\
8 \\
8 \\
8\end{array}$ & $\begin{array}{c}\text { シ 驾ずか } \\
8 \\
8 \\
8 \\
0\end{array}$ & $\begin{array}{l}1 \\
0 \\
0 \\
+ \\
+ \\
+\end{array}$ & $\begin{array}{l}\stackrel{0}{8} \\
8 \\
0 \\
\times \\
0\end{array}$ & $\begin{array}{l}8 \\
8 \\
8 \\
8 \\
0\end{array}$ & $\begin{array}{l}8 \\
8 \\
8 \\
0 \\
0\end{array}$ & $\begin{array}{c}\text { シ 另ずか } \\
\bigcirc \\
\bigcirc \\
\bigcirc \\
0\end{array}$ & $\begin{array}{c}0 \\
0 \\
0 \\
0 \sim 4 \\
0 \\
0\end{array}$ \\
\hline $\begin{array}{r}9 \\
11 \\
14 \\
.22 \\
36 \\
37\end{array}$ & $\begin{array}{l}x \\
0 \\
0 \\
x \\
\times x \\
x\end{array}$ & $\begin{array}{l}8 \\
8 \\
8 \\
8 \\
0\end{array}$ & $\begin{array}{l}8 \\
8 \\
8 \\
8 \\
8 \\
0\end{array}$ & $\begin{array}{l}8 \\
8 \\
8 \\
8 \\
8 \\
0\end{array}$ & $\begin{array}{l}0 \\
+ \\
0 \\
+ \\
0 \\
+\end{array}$ & $\begin{array}{l}x \\
0 \\
0 \\
x \times \\
x \times \\
x\end{array}$ & $\begin{array}{l}8 \\
8 \\
8 \\
8 \\
0\end{array}$ & $\begin{array}{l}8 \\
8 \\
8 \\
8 \\
0\end{array}$ & $\begin{array}{l}0 \\
8 \\
8 \\
8 \\
0\end{array}$ & $\begin{array}{l}0 \\
0 \\
0 \\
0 \\
0 \\
0\end{array}$ \\
\hline $\begin{array}{l}2 \\
3 \\
4 \\
5\end{array}$ & $\begin{array}{c}0 \\
x \\
x \\
x \\
x\end{array}$ & $\begin{array}{l}0 \\
0 \\
\times x \\
\times \times\end{array}$ & $\begin{array}{l}\bigcirc_{x \times x} \\
x \times\end{array}$ & $\begin{array}{l}0 \\
8 \\
0 \\
0\end{array}$ & $\begin{array}{c}9 \sim 10 \\
2 \sim 9 \\
260 \sim 270 \\
86 \sim 125\end{array}$ & $\begin{array}{l}0 \\
\times x \\
0 \\
0\end{array}$ & $\underset{\substack{x \times x \\
x \times x}}{0}$ & $\begin{array}{l}0 \\
\times x \times \\
x \times\end{array}$ & $\begin{array}{c}\text { 局部腐食約10点 } \\
8 \\
8\end{array}$ & $\begin{array}{r}2 \sim 100 \\
1 \sim 13 \\
320 \sim 570 \\
160 \sim 300\end{array}$ \\
\hline $\begin{array}{l}17 \\
18 \\
21\end{array}$ & $\begin{array}{l}8 \\
8\end{array}$ & $\begin{array}{l}8 \\
8\end{array}$ & $\begin{array}{l}O \\
O \\
\times\end{array}$ & 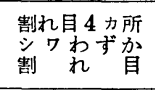 & $\begin{array}{l}0 \\
0 \\
+\end{array}$ & $\begin{array}{l}8 \\
8 \\
0\end{array}$ & 8 & $\begin{array}{l}8 \\
\times \\
x\end{array}$ & 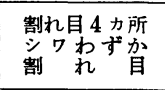 & 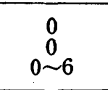 \\
\hline $\begin{array}{l}10 \\
15 \\
16\end{array}$ & $\begin{array}{l}x \times x \\
\times \times x \\
0\end{array}$ & $\begin{array}{l}x \times \\
x \times \\
0\end{array}$ & $\begin{array}{l}x \times \\
\times \times x \\
x \times\end{array}$ & $\begin{array}{l}8 \\
8 \\
0\end{array}$ & $=$ & $\begin{array}{l}x \times x \\
\times x \times x \\
0\end{array}$ & $\begin{array}{l}x \times \\
x \times \\
0\end{array}$ & $\begin{array}{l}x \times x \\
\times \times \times \\
\times \times x\end{array}$ & $\begin{array}{l}8 \\
8 \\
0\end{array}$ & $\bar{z}$ \\
\hline
\end{tabular}

○：異状なし， $\times$ ：わずか， $\times \times$ : やや多し， $\times \times \times:$ はなはだしい

訩断值: 単位 $\mu \mathrm{A}$ (電解液, 淡水) 
に, 水分が任意に均一に分散しているという仮定が満足 されず，過小の值が出たものと考光られる。

\section{4. 浸 漬 試 験}

試験片は昭和 30 年 11 月より翌年 1 月の間に叙装し, 周辺泣ギルソナイトとブロンアスフォルトとの混合物で シールし保護した (図 1 参照)。これらを 31 年 4 月千手 発電所連絡水槽の制水門屝 (高さ約 $6.4 \mathrm{~m}$, 幅約 $6 \mathrm{~m}$ ) に取り付け, 同月 27 日より水中に浸漬せしめた（図 2 参 照)。門屝と試験片を電気的に絶縁するため, 締付ボル トにビニルテープを巻き，座金にはゴムパッキンを使用 した。門屝はほとんど常時水中に没している。水槽中の 水注信川より引いたものであり，比抵抗は 8,000 $20,000 \Omega-\mathrm{cm}$ 程度で普通約 $10,000 \Omega-\mathrm{cm}$ で中性であ り, 水温注冬期 $3 \sim 7^{\circ} \mathrm{C}$, 夏期 $27^{\circ} \mathrm{C}$ 程度である。

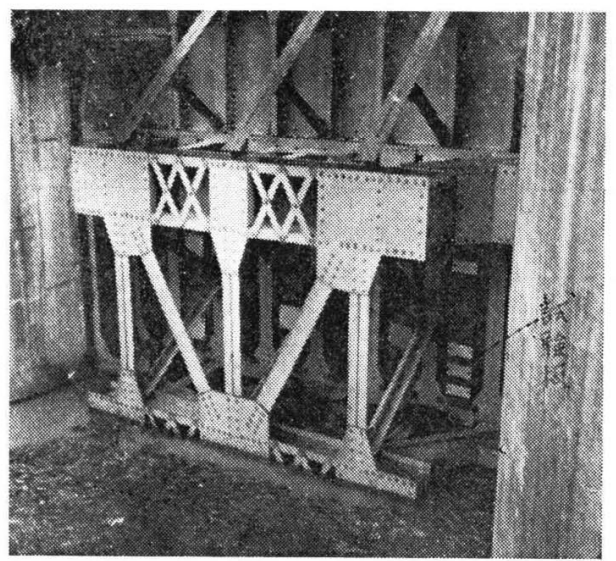

図 $2 \mathbf{A}$ 制水門扉図

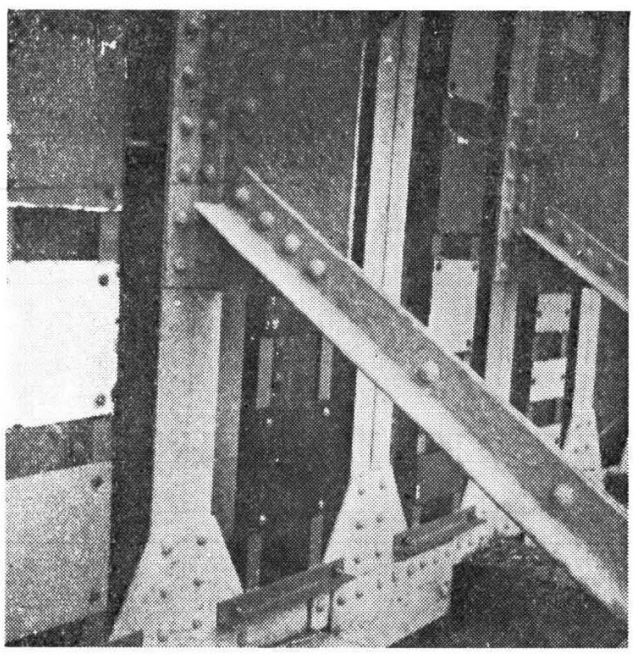

図 2 B 制水門屝への試験片取り付け状態

塗膜状態の調査観察には門屝を引きあげ, 塗装面に付 着した泥（厚さ $1 \mathrm{~mm}$ 以下）を軽く水洗し取り除き， 肉眼観察および塗膜㟝断器による塗膜通電量によりその
劣化状況を調べ，一部は写真撮影を行なった。中間調査 の結果は表 3 のごとくであり, 昭和 34 年 9 月 15 日試験 を終了した（従って浸漬試験期間は約 3 年半にわたっ た)。

試験終了時の試料の大部分の叙膜劣化状況写真を図 3 に示した。

水中浸漬時の叙膜劣化に及ぼす流速の影響を調べるた め図 4 に示すごとき木製いかだを作製し，これに試駼片 を取り付け門屝付近の水上に浮遊せしめ浸漬試験を併行 して行なったが, 放流時に門屝と激しく衝突し, 試験片 の多く安流失したので本報告ではその結果は省略した。

\section{5. 試験結果の考察}

$\tan \delta$ 測定打よび浸漬試験の結果によって, 各染料の 防食性を $\mathrm{A}, \mathrm{B}, \mathrm{C}$ の 3 級に分類し，相互に比較すると 表 4 および表 5 のごとくになる。 $\tan \delta$ の值による分類 の基準は表中に示した通りである。浸漬試験結果の判定 は塗膜診断值と観察の結果によって行なったもので，定 量的な基準は定め難いが, 各試料の腐食の程度にはかな りの差があるので分類に困難はなかった。

二つの方法による防食性判定の結果の間にはほぼ平行

表 $4 \tan \delta$ 測定法と浸漬試験による染料の防食性 判定の比較

\begin{tabular}{|c|c|c|c|}
\hline & 試片番号 & 漫 清 試 験 & $\tan \delta$ 法 \\
\hline 油 性 系 & $\begin{array}{l}23 \\
24 \\
25 \\
13\end{array}$ & $\begin{array}{l}\mathrm{C} \\
\mathrm{C} \\
\mathrm{C} \\
\mathrm{B}\end{array}$ & $\begin{array}{l}\mathrm{B} \\
\mathrm{B} \\
\underline{B} \\
-\end{array}$ \\
\hline 石炭酸樹脂采 & $\begin{array}{r}1 \\
6 \\
12 \\
28 \\
29 \\
30 \\
31\end{array}$ & $\begin{array}{l}\mathrm{B} \\
\mathrm{C} \\
\mathrm{B} \\
\mathrm{B} \\
\mathrm{B} \\
\mathrm{A} \\
\mathrm{A}\end{array}$ & $\begin{array}{l}- \\
\bar{A} \\
\mathrm{~A} \\
\mathrm{~A} \\
\mathrm{~A} \\
\mathrm{~B}\end{array}$ \\
\hline 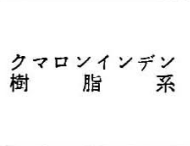 & $\begin{array}{r}7 \\
8 \\
32 \\
33 \\
34 \\
35\end{array}$ & $\begin{array}{l}\text { A } \\
\text { A } \\
\text { A } \\
\text { A } \\
\text { A }\end{array}$ & $\begin{array}{l}\mathrm{A} \\
\mathrm{A} \\
\mathrm{A} \\
\mathrm{A} \\
\mathrm{B} \\
\mathrm{A}\end{array}$ \\
\hline 塩化ピ $=儿$ 樹脂采 & $\begin{array}{r}99 \\
11 \\
14 \\
22 \\
36 \\
37\end{array}$ & $\begin{array}{l}\text { A } \\
\text { A } \\
\text { A } \\
\text { A } \\
\text { A }\end{array}$ & $\begin{array}{l}\bar{Z} \\
\overline{\bar{A}} \\
\mathrm{~A}\end{array}$ \\
\hline 淈 青 系 & $\begin{array}{l}2 \\
3 \\
4 \\
5\end{array}$ & $\begin{array}{l}\mathrm{C} \\
\stackrel{\mathrm{B}}{\mathrm{C}} \\
\mathrm{C}\end{array}$ & $\begin{array}{l}\stackrel{\mathrm{B}}{\mathrm{C}} \\
=\end{array}$ \\
\hline $\begin{array}{l}\geq \\
I\end{array}-\mu g-n$ & $\begin{array}{l}17 \\
18 \\
21\end{array}$ & $\begin{array}{l}\text { A } \\
\text { B } \\
B\end{array}$ & $\bar{z}$ \\
\hline ジクリシ & $\begin{array}{l}10 \\
15 \\
16\end{array}$ & $\begin{array}{l}\mathrm{C} \\
\stackrel{c}{c}\end{array}$ & $\bar{z}$ \\
\hline
\end{tabular}

$\tan \delta$ 值による塗料の防食性判定の基準

\begin{tabular}{|c|c|}
\hline 分 類 & $\tan \delta$ 值 \\
\hline $\begin{array}{l}\mathrm{A} \\
\mathrm{B} \\
\mathrm{C}\end{array}$ & $\begin{array}{c}<0.15 \\
>0.25 \\
>0.25\end{array}$ \\
\hline
\end{tabular}




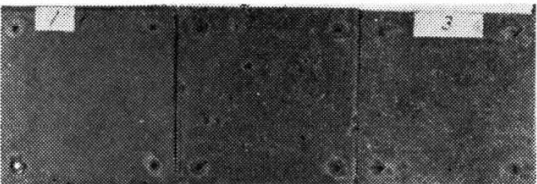

No. 1

No. 2

No. 3

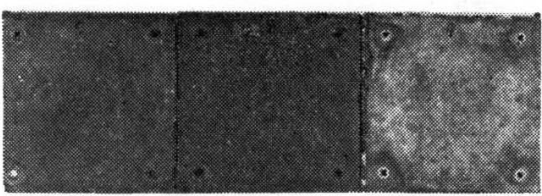

No. 7

No. 8

No. 9

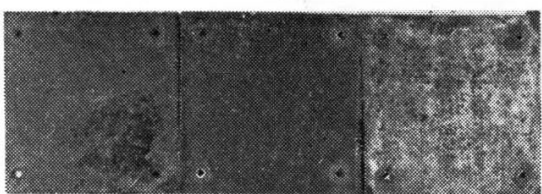

No. 15

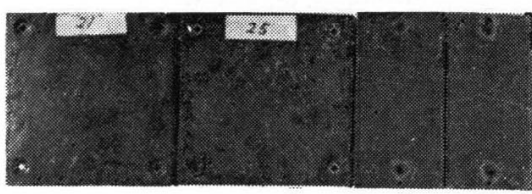

No. 21

No. 25

No. 28, 29

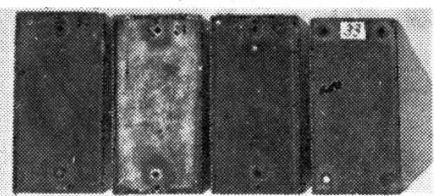

No. 30 No. 31 No. 32 No. 33

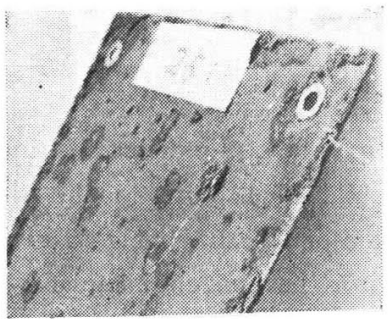

No. 25

表 $5 \tan \delta$ 法と浸漬試験による分類の比較

\begin{tabular}{|c|c|c|c|}
\hline $\tan \delta$ 法 & A & B & C \\
\hline$\stackrel{\mathrm{A}}{\mathrm{B}}$ & $\begin{array}{l}8 \\
2 \\
0\end{array}$ & $\begin{array}{l}2 \\
1 \\
1\end{array}$ & $\begin{array}{l}0 \\
4 \\
0\end{array}$ \\
\hline
\end{tabular}

性が認められ，叙膜の劣化開始前における $\tan \delta$ の值， 換言すれば，叙膜のイオン透過性よりその叙装の耐久力 を判定することは，この試験のような条件の場合におい ても有効なことが明らかにされた。

耐水性がこの試験の条件下の防食塗装の耐久力の重要

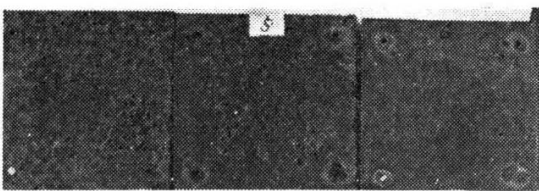

No. 4

No. 5

No. 6

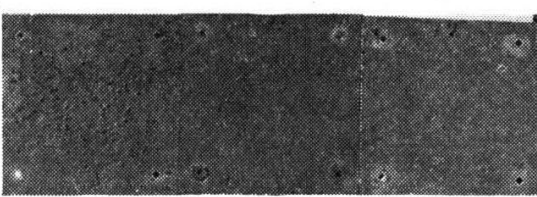

No. 10

No. 11

No. 12

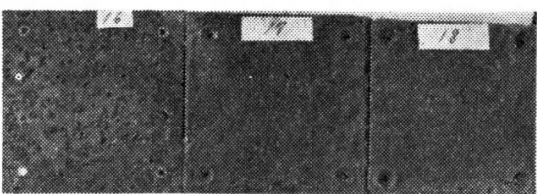

No. 16

No. 17

No. 18

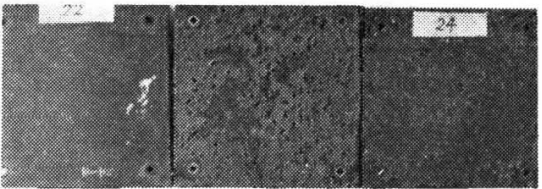

No. 22

No. 23

No. 24

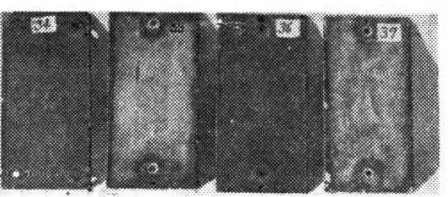

$\begin{array}{llll}\text { No. } 34 & \text { No. } 35 & \text { No. } 36 & \text { No. } 37\end{array}$
図 3 塗膜の劣化状況
な因子となること垱 然予期されたことであ り, 表 2 の吸水量の值 によっても吸水量の小 さいものが概して良好 な耐久力を示している が，瀝青系叙料のごと くに吸水量が小さくて も耐久力の悪いものも あるので, これのみで は断定できない。

塗料の種類による防 食性の差異を比較する と, クマロン樹脂系, ビニル樹脂系, コール タールエナメルがすぐ れており，他はこれら より劣っている。

この三者を比較する とビニル樹脂系は塗装 前の下地処理を特に入 念に行なう必要がある ので，このための経費 が大きくなる欠点があ る。クマロン樹脂系は 日光の照射を受けると 速に白垔化を起こすの で，常時水中にある門 屝にのみ使用すること ができる。コールター ルエナメル生加熱溶融 して塗装するので，実 際に門扉に塗装を行な うにはかなりの困難が あるために実用範囲は 限られる。

油性系, 浾青系は一般に劣っている。石炭酸樹脂系の 中には良好なものもあるが，品種による差が大きいの で，この系統のものを使用する場合には予備試験を必要 とする。ジンクリッチペイントは原理的には良いはずで あるが，試験の結果は良くなかった。特に早期にふくれ の出る欠点が目立った。これは打とらく亜鉛が水酸化亜 鉛などに変化する際体皘を增し，塗膜の接着力がないた めにふくれるものとも考元られる。これらの点に今後品 質改善の余地が多い。

結論としてはこの試験で良好な成績であった 3 種の塗 料の中から現場の塗装条件に適したものを選ぶのが最も 


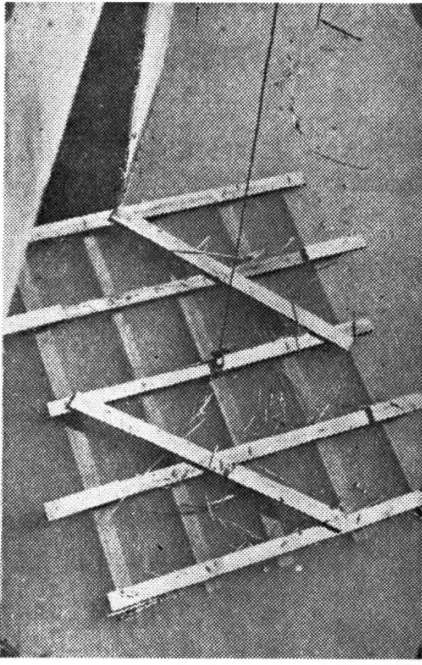

図 $4 \mathrm{~A}$ 試験片取付筏
良いと考えられる が, 比較的安価な 石炭酸樹脂系塗料 の中から予備試験 を行なった上で， その成績の艮いも のを使用するのも 一つの方法と思わ れる。

終りに当り本試 験に協力頂いた国 鉄給電管理事務所 三上良雄氏ならび に千手発電区の諸 氏に深謝の意を表 する。

(昭和 37 年 5 月 30 日受理)

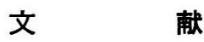

1) S. M. Gleser: Corrosion, 14, $377 \mathrm{t}$ (1958)

2) P. M. Hess: ibid, 14, 111 (1958)

3) 岡本 用, 諸住 高: 電気化学, 23, 15 (1955)

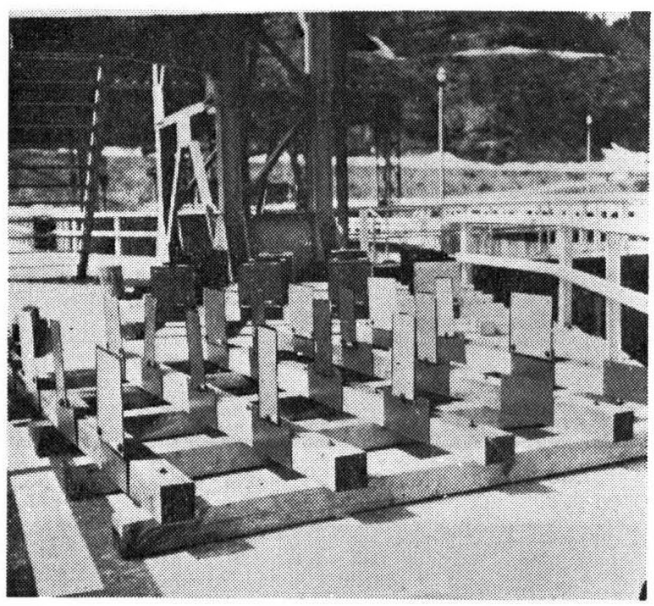

図 $4 \mathrm{~B}$ 試験片の茷への取付状態

4) F.E. Pschorr: Corrosion, 17, $532 \mathrm{t}$ (1961)

5) 岡本 㣚, 三谷幸雄, 永山政一: 電気化学, 24, 69 (1956) Gerischer: Z. Elektrochem, 58, 9 (1954)

6) D. M. Brasher \& A.H. Kingsburg: J. Appl. Chem., 4, 62 (1954)

7）矢野 泰：色材, 24, 81 (1951)

\section{アミン類を主剂とする防食剤の研究（第 22 報） インヒビターの吸着機構一その $1^{*}$} 荒牧国次**大矢徹 $* * *$ 藤井晴一**

\section{Amine-Type Corrosion Inhibitors (22 nd Report) Adsorption Mechanism of Inhibitors-Part 1}

\section{Kunitsugu Aramaki, Tôru Ôya and Seiichi Fujii}

Corrosion inhibition efficiencies of $\boldsymbol{n}$-dodecyl amine in which hydrogen is substituted by phenyl, $\boldsymbol{o}$-tolyl, $m$-tolyl, $p$-tolyl, cyclohexyl or benzyl radical were determined both in a neutral saline water and in an acidic solution. Among the phenyl and tolyl substituted amines of which basic strength is equally weak, N-o-tolyl or $\mathrm{N}$ $\boldsymbol{p}$-tolyl-n-dodecylamine is a more effective inhibitor than $\mathrm{N}$-phenyl- or $\mathrm{N}$ - $\boldsymbol{m}$-tolyl-n-dodecylamine, because nitrogen atom of the former two amines has more mobile unshared pairs of electrons than the latter two. These data indicate that these amines are chemically adsorbed by means of coordination of the electrons to metals.
$\mathrm{N}$-cyclohexyl or N-benzyl-n-dodecylamine containing more mobile lone pairs in the nitrogen atom is more chemically adsorbable in a neutral aqueous solution or in benzene solution. In a strong acid solution, however, corrosion inhibition of these amines is the less effective at low concentration, because these are capable of forming ammonium ions which are reversibly adsorb. ed by virtue of electrostatic attraction. Protons attract the adsorbed amine molecules from the metal surface, leaving non-protected metal. Thus, only in case of a dilute solution of inhibitor in a strong acid medium, weak base amines may be more effective than strong ones. 